\title{
Contraceptive practices: an experience from ever married women in a city of Maharashtra, India
}

\author{
Priyanka Chintaram Sahu ${ }^{1 *}$, Ismail ali Farukh ali Inamdar ${ }^{2}$, Mohan K. Doibale ${ }^{2}$
}

\author{
${ }^{1}$ Department of Community Medicine, NIMS Medical College, Jaipur, Rajasthan, India \\ ${ }^{2}$ Department of Community Medicine, Dr. S. C. GMC, Nanded-431601, Maharashtra, India
}

Received: 10 January 2015

Accepted: 14 February 2015

\section{*Correspondence:}

Dr. Priyanka Chintaram Sahu,

E-mail: piyusahu13@gmail.com

Copyright: (C) the author(s), publisher and licensee Medip Academy. This is an open-access article distributed under the terms of the Creative Commons Attribution Non-Commercial License, which permits unrestricted non-commercial

\begin{abstract}
Background: The single most important problem that India is facing now is the uncontrolled growth of population. In today's scenario, fertility control is the most important way to check high population growth. In spite of availability of a wide range of contraceptives and mass media campaigns and IEC programs, the population control remains a distant dream to achieve. Objectives: 1) To determine prevalence of contraceptive acceptance and the type of contraceptive used. 2) To identify factors influencing the contraceptive acceptance pattern in the study area. 3) To assess the reasons for not accepting contraceptive methods by ever married women.

Methods: A community based cross sectional descriptive study was conducted from January 2011 to June 2011 at Nanded city in Maharashtra state over 790 ever married women from 15-49 years age group with 2 stage sampling technique.

Results: Prevalence of contraceptive use among study subjects was 483 (64.41\%). Tubectomy 388 (80.33\%) was method of choice for family planning accepted by the couples. There was significant association between contraceptive practice and age, type of family, education, socioeconomic status, age at marriage, years of marriage and no. of children of study subject. Most common reasons behind not using contraceptive were family not completed $100(37.45 \%)$.

Conclusions: Female tubectomy is still a method of choice among all contraceptives. Various socio-demographic and reproductive variables had impact on contraceptive practices. Majority couples not using contraceptive desire to have children to complete family.
\end{abstract}

Keywords: Contraceptive practice, Ever married women, India

\section{INTRODUCTION}

Family planning has been cited as essential to the achievement of Millennium Development Goals (MDG) and is an important indicator for tracking progress on improving maternal health. Family planning has a direct impact on women's health and well-being as well as on the consequence of each pregnancy. ${ }^{1}$

The single most important problem that India is facing now is the uncontrolled growth of population. ${ }^{2}$ India adds about 10 lakh persons to its population every fortnight and adds about one Australia every eight month. According to census 2011, Indian population stood at $1,21,01,93,422$. The last decade has seen India's population growth by $17.64 \% .^{3}$

In today's scenario, fertility control is the most important way to check high population growth. Fertility is directly influenced by a set of social and biological factors and ${ }^{4}$ fertility pattern influences the demographic profile and development status of the community. Human fertility is determined by age at marriage, customs, habits, education, socio-economic status all of which affect 
fertility and demographers opine that socio-economic development decreases the family size. ${ }^{5}$

India was the first country in the world to formulate the national family planning programme in the year 1952 with the objective of reducing the birth rate of the extent necessary to stabilize the population at a level consistent with requirement of national economy. ${ }^{6}$ Since then its name has changed to family welfare programme and lastly to the present Reproductive and Child Health $(\mathrm{RCH})$ programme. This change was made particularly to emphasize more and also to increase the acceptance of contraceptive methods by reproductive age group people. $^{7}$

In spite of availability of a wide range of contraceptives and mass media campaigns and IEC programs, the population control remains a distant dream to achieve. It is pertinent to identity the factors responsible for poor acceptance of family planning program in different sociocultural and socio-economic groups. ${ }^{2}$ Inspite of substantial investment and efforts made by the government, no satisfactory result has yet been achieved and the present rate of contraceptive users is far behind the national goal of Couple Protection Rate (CPR) $60 \%$ by 2000 to achieve a Net Reproduction Rate (NRR) of $1 .^{7}$

The extent of acceptance of contraceptive methods still varies within societies and also among different castes and religious groups. The factors responsible for such varied picture operate at the individual, family and community level with their root in the socioeconomic and cultural milieu of Indian society. Women need to decide when to start and finish childbearing, how long to wait after the birth of one child before becoming pregnant with the next and how many children to have. ${ }^{3}$ Success of contraceptive practice lies in the acceptance of a regular contraceptive to prevent future pregnancies. ${ }^{8}$

Unmet needs is often described as a problem of access and interpreted as that women do not use contraceptives because they cannot find or afford them. While access is an issue, many other reasons have been cited by women for not using contraceptives, including lack of knowledge, cultural, personal, religious oppositions, health concerns, and fear of side effects. ${ }^{1}$

Thus it is needed to determine prevalence of contraceptive acceptance and the type of contraceptive used, to identify factors influencing the contraceptive acceptance pattern and to assess the reasons for not accepting contraceptive methods by ever married women.

\section{METHODS}

\section{Study design}

It was a community based cross sectional descriptive study.

\section{Study period}

Study was conducted during January 2011 to June 2011.

\section{Study site and population}

A community based survey was conducted at Nanded city in Maharashtra state. The total population of the city was 430733 distributed in 65 municipal corporation wards. The municipal corporation is further organized into five geographical divisions for effective service delivery and management.

\section{Pilot study}

Pilot study was conducted at one municipal corporation ward (ward no 2.) of the city for correction of study questionnaire and to check feasibility of study. Depending upon outcome, necessary corrections were made and the pilot ward was skipped while selecting sample for the study.

\section{Sample size calculation}

According to NFHS 3 survey in Maharashtra, $66.9 \%$ women were using contraceptives, ${ }^{9}$ Thus, sample size ${ }^{10}$ was calculated as 790 taking $66.9 \%$ prevalence, $95 \%$ confidence interval and $5 \%$ allowable error.

\section{Sampling procedure}

Study subjects were selected by 2 stage sampling technique.

First stage: $10 \%$ (7) wards were selected from 65 wards by simple random sampling using lottery method

Second stage: 113 couples selected from each ward using systematic random sampling.

\section{Inclusion criteria}

Ever married women of reproductive age group (15-49 years) were included in the study.

\section{Exclusion criteria}

Pregnant women, women within puerperal period $(<42$ days of delivery) and seriously ill women were excluded from the study.

\section{Data collection process}

Participation in the study was purely on voluntary basis. Before start of the study, they were assured of confidentiality about information obtained from them. The data were collected by interview of the female partner by house to house visit with the help of a predesigned and pre-tested schedule. The face to face 
interview was carried out in local language (Marathi/ Hindi).

\section{Study variables}

Socio-demographic variables: Age, religion, education, type of family, working status, socioeconomic status (B. G. Prasad classification) of study subjects.

Reproductive variables: Age at marriage, age at first child birth, No. of abortions, and No. of living children to study subjects.

Information about contraceptive practice: Using contraceptive or not, type of contraceptive used, reason behind non acceptance in those not using contraceptives.

\section{Statistical analysis}

Data analysis was carried out with the help of statistical measures, such as percentages, proportion, Chi square test and Chi square test for trend using software graph pad prism version 5.01 and open Epi version 2.3.

\section{Reference citation}

Reference citation was done by Vancouver referencing style. ${ }^{11}$

\section{RESULTS}

\section{Contraceptive practices}

Among 790 couples, 750 couples participated in the study with response rate of $94.94 \% .483$ (64.41\%) study subjects were using contraceptive methods while 267 (35.59\%) had not accepted any one (Table 1).

Table 1: Prevalence of contraceptive acceptance among respondents $(n=750)$.

\begin{tabular}{|ll|} 
Contraceptive & $\begin{array}{l}\text { Number of } \\
\text { respondents } \\
(\%)\end{array}$ \\
\hline User & $483(64.41)$ \\
\hline Non user & $267(35.59)$ \\
\hline Total & $750(100)$ \\
\hline
\end{tabular}

\section{Types of contraceptive used}

Tubectomy 388 (80.33\%) was method of choice for family planning accepted by the couples followed by condom $53(10.97 \%)$ and oral contraceptive pills 23 $(4.76 \%)$.

Only one couple accepted vasectomy as family planning method. Only $03(0.40 \%)$ of women were using the different other non-approved methods (safe period, withdrawal method) of contraception (Table 2).
Table 2: Distribution of respondents according to type of contraceptive used $(n=483)$.

\begin{tabular}{|ll|}
\hline $\begin{array}{l}\text { Type of } \\
\text { contraceptive } \\
\text { used }\end{array}$ & $\begin{array}{l}\text { Number of } \\
\text { respondents } \\
(\%)\end{array}$ \\
\hline Condom & $53(10.97)$ \\
\hline IUCD & $15(3.11)$ \\
\hline Tubectomy & $388(80.33)$ \\
\hline OC Pills & $23(4.76)$ \\
\hline Vasectomy & $01(0.13)$ \\
\hline Safe period & $03(0.40)$ \\
\hline Total & $483(100)$ \\
\hline
\end{tabular}

\section{Socio-demographic variables and contraceptive practice}

Most 169 (22.53\%) of the women were in the age group of 25-29 years. The contraceptive practice was significantly increased $(\mathrm{P}<0.001)$ with the increase of the age of female. There was significant $(\mathrm{P}<0.001)$ association between type of family and contraceptive practice. Majority $394(52.53 \%)$ study subjects were Buddha by religion while the contraceptive practice not differed significantly $(\mathrm{P}>0.05)$ with the difference of religion. $190(25.33 \%)$ women were working while 560 $(74.47 \%)$ were housewives. There was significant difference $(\mathrm{P}<0.05)$ in contraceptive practice among working women and housewives. Most 198(26.4\%) of the women were literate up to secondary level. The contraceptive practice significantly $(P<0.01)$ differed with the difference of literacy status of the woman. The contraceptive practices were high among those belonging to higher socioeconomic class, but the difference was not statistically significant $(\mathrm{P}>0.05)$ (Table 3$)$.

\section{Reproductive variables and contraceptive practices}

The contraceptive practice decreased significantly with increase in age at marriage $(\mathrm{P}<0.0001)$ and increase in age at first child birth ( $\mathrm{P}<0.05)$. Majority 289 (38.53\%) of women were married since $11-20$ years. The contraceptive practice increased significantly $(\mathrm{P}<0.0001)$ with increase in duration of marriage. It was maximum $(81.9 \%)$ among women having 3-4 living children and it differed significantly ( $\mathrm{P}<0.0001)$ with the difference of number of living children (Table 4 ).

\section{Reasons of non-acceptance of contraceptive methods}

Most common reasons behind not using contraceptive were family not completed $100(37.45 \%)$ followed by worry about side effects 48 (17.98\%) and opposition from family $27(10.11 \%)$. Other reasons for not using contraceptives were infrequent sex 14 (5.24\%), menopause 8 (3\%), hysterectomy $9(3.37 \%)$, breast feeding 7 (2.62\%), anti-religion 14 (5.24\%), no knowledge about source $24(8.99 \%)$, cost too much 13 $(4.87 \%)$, inconvenient to use $21(7.87 \%)$ and following natural family planning method $15(5.62 \%)$ (Table 5). 
Table 3: Association of socio-demographic variables with contraceptive practice $(n=750)$.

\begin{tabular}{|c|c|c|c|c|c|}
\hline \multirow{2}{*}{$\begin{array}{l}\text { Socio-demographic } \\
\text { variables }\end{array}$} & \multirow{2}{*}{ Group (year) } & \multicolumn{2}{|c|}{ Contraceptive use } & \multirow{2}{*}{ Total $(\%)$} & \multirow{2}{*}{ Test of significance } \\
\hline & & Yes $(\%)$ & No $(\%)$ & & \\
\hline \multirow{7}{*}{$\begin{array}{l}\text { Age of respondents } \\
\text { (years) }\end{array}$} & $15-19$ & $1(2.86)$ & $34(97.14)$ & $35(100)$ & \multirow{7}{*}{$\begin{array}{l}\chi^{2}-111.7 \\
\text { df }-5, P<0.0001 \\
\chi^{2} \text { test for trend }-55.21, \\
d f-1, P<0.0001\end{array}$} \\
\hline & $20-24$ & $42(36.52)$ & $73(63.48)$ & $115(100)$ & \\
\hline & $25-29$ & $111(65.68)$ & $58(34.32)$ & $169(100)$ & \\
\hline & $30-34$ & $122(78.71)$ & $33(21.29)$ & $155(100)$ & \\
\hline & $35-39$ & $98(77.17)$ & $29(22.83)$ & $127(100)$ & \\
\hline & $40-44$ & $62(74.7)$ & $21(25.3)$ & $83(100)$ & \\
\hline & $45-49$ & $47(71.21)$ & $19(28.79)$ & $66(100)$ & \\
\hline \multirow{3}{*}{ Type of family } & Joint & $58(53.7)$ & $50(46.3)$ & $108(100)$ & \multirow{3}{*}{$\begin{array}{l}\chi^{2}-15.91 \\
\text { df }-2, P-0.0004\end{array}$} \\
\hline & Nuclear & $294(70.5)$ & $123(29.5)$ & $417(100)$ & \\
\hline & Three gene & $131(58.22)$ & $94(41.78)$ & $225(100)$ & \\
\hline \multirow{4}{*}{ Religion } & Hindu & $133(63.03)$ & $78(36.97)$ & $211(100)$ & \multirow{4}{*}{$\begin{array}{l}\chi^{2}-0.786 \\
\text { df }-3, p-0.8528\end{array}$} \\
\hline & Muslim & $79(62.2)$ & $48(37.8)$ & $127(100)$ & \\
\hline & Buddha & $259(65.74)$ & $135(34.26)$ & $394(100)$ & \\
\hline & Other & $12(66.67)$ & $6(33.33)$ & $18(100)$ & \\
\hline \multirow{2}{*}{ Working status } & Working & $136(71.58)$ & $54(28.42)$ & $190(100)$ & \multirow{2}{*}{$\begin{array}{l}\chi^{2}-5.72 \\
d f-1, P-0.017\end{array}$} \\
\hline & Housewife & $347(61.96)$ & $213(38.04)$ & $560(100)$ & \\
\hline \multirow{6}{*}{$\begin{array}{l}\text { Education of } \\
\text { respondents }\end{array}$} & Illiterate & $140(71.43)$ & $56(28.57)$ & $196(100)$ & \multirow{6}{*}{$\begin{array}{l}\chi^{2}-18.26 \\
d f-5, P-0.0026 \\
\chi^{2} \text { test for trend }-9.747 \\
d f-1, P-0.0018\end{array}$} \\
\hline & Primary & $59(78.67)$ & $16(21.23)$ & $75(100)$ & \\
\hline & Middle & $98(61.64)$ & $61(38.36)$ & $159(100)$ & \\
\hline & Secondary & $112(56.57)$ & $86(43.43)$ & $198(100)$ & \\
\hline & HSC & $50(58.14)$ & $36(41.86)$ & $86(100)$ & \\
\hline & Graduation \& PG & $24(66.67)$ & $12(33.33)$ & $36(100)$ & \\
\hline \multirow{5}{*}{$\begin{array}{l}\text { Socioeconomic } \\
\text { status } \\
\text { (B. G. Prasad } \\
\text { classification) }\end{array}$} & I & $12(70.59)$ & $5(29.41)$ & $17(100)$ & \multirow{5}{*}{$\begin{array}{l}\chi^{2}-4.678 \\
\text { df }-4, P-0.3219 \\
\chi^{2} \text { test for trend }-0.00017 \\
d f-1, P-0.9895\end{array}$} \\
\hline & II & $21(75)$ & $7(25)$ & $28(100)$ & \\
\hline & III & $23(57.5)$ & $17(42.5)$ & $40(100)$ & \\
\hline & IV & $75(58.59)$ & $53(41.41)$ & $128(100)$ & \\
\hline & $\mathrm{V}$ & $352(65.55)$ & $185(34.45)$ & $537(100)$ & \\
\hline
\end{tabular}

Table 4: Association of reproductive variables with contraceptive practice $(n=750)$.

\begin{tabular}{|c|c|c|c|c|c|}
\hline \multirow{2}{*}{ Reproductive variables } & \multirow{2}{*}{ Group } & \multicolumn{2}{|c|}{ Contraceptive use } & \multirow{2}{*}{ Total $(\%)$} & \multirow{2}{*}{ Test of significance } \\
\hline & & Yes $(\%)$ & No $(\%)$ & & \\
\hline \multirow{5}{*}{ Age at marriage (years) } & $\leq 14$ & $127(73.84)$ & $45(26.16)$ & $172(100)$ & \multirow{5}{*}{$\begin{array}{l}\chi^{2}-32.47 \\
d f-4, P<0.0001 \\
\chi^{2} \text { test for trend }-18.08 \\
d f-1, P<0.0001\end{array}$} \\
\hline & $15-16$ & $199(70.07)$ & $85(29.93)$ & $284(100)$ & \\
\hline & $17-18$ & $72(48.65)$ & $76(51.35)$ & $148(100)$ & \\
\hline & $19-20$ & $53(64.63)$ & $29(35.37)$ & $82(100)$ & \\
\hline & $\geq 21$ & $32(50)$ & $32(50)$ & $64(100)$ & \\
\hline \multirow{4}{*}{$\begin{array}{l}\text { Age at first child birth } \\
\text { (years) }\end{array}$} & $\leq 16$ & $201(77.31)$ & $59(22.69)$ & $260(100)$ & \multirow{4}{*}{$\begin{array}{l}\chi^{2}-10.99 \\
d f-3, P-0.0118 \\
\chi^{2} \text { test for trend }-8.534 \\
d f-1, P-0.0035\end{array}$} \\
\hline & $17-18$ & $130(67.36)$ & $63(32.64)$ & $193(100)$ & \\
\hline & $19-20$ & $79(63.71)$ & $45(36.29)$ & $124(100)$ & \\
\hline & $\geq 21$ & $72(64.86)$ & $39(35.14)$ & $111(100)$ & \\
\hline \multirow{4}{*}{ Years of marriage } & $\leq 10$ & $103(40.39)$ & $152(59.61)$ & $255(100)$ & \multirow{4}{*}{$\begin{array}{l}\chi^{2}-98.25 \\
d f-3, P<0.0001 \\
\chi^{2} \text { test for trend }-57.72 \\
d f-1, P<0.0001\end{array}$} \\
\hline & $11-20$ & $227(78.55)$ & $62(21.45)$ & $289(100)$ & \\
\hline & $21-30$ & $129(73.71)$ & $46(26.29)$ & $175(100)$ & \\
\hline & $\geq 31$ & $24(77.42)$ & $7(22.58)$ & $31(100)$ & \\
\hline \multirow{6}{*}{ No. of children } & $\leq 2$ & $89(34.50)$ & $169(65.50)$ & $258(100)$ & \multirow{6}{*}{$\begin{array}{l}\chi^{2}-155.1 \\
\text { df }-2, P<0.0001 \\
\chi^{2} \text { test for trend }-98.95 \\
d f-1, P<0.0001\end{array}$} \\
\hline & $3-4$ & $285(81.9)$ & $63(18.1)$ & $348(100)$ & \\
\hline & $>4$ & $109(75.69)$ & $35(24.31)$ & $144(100)$ & \\
\hline & 0 & 384 (64.97) & $207(35.03)$ & $591(100)$ & \\
\hline & 1 & $70(63.64)$ & $40(36.36)$ & $110(100)$ & \\
\hline & $\geq 2$ & $29(59.18)$ & $20(40.82)$ & $49(100)$ & \\
\hline
\end{tabular}


Table 5: Distribution of married women according to reasons for not accepting contraceptives.

\begin{tabular}{|ll|}
\hline Reasons for not accepting contraceptives & $\begin{array}{l}\text { No. of women } \\
(\%)(\mathbf{n = 2 6 7 )}\end{array}$ \\
\hline Infrequent sex & $14(5.24)$ \\
\hline Menopausal & $08(3)$ \\
\hline Hysterectomy & $09(3.37)$ \\
\hline Breast feeding & $07(2.62)$ \\
\hline Family not complete & $100(37.45)$ \\
\hline Opposition from family & $27(10.11)$ \\
\hline Anti-religion & $14(5.24)$ \\
\hline No knowledge about source & $24(8.99)$ \\
\hline Worry about side effects & $48(17.98)$ \\
\hline Cost too much & $13(4.87)$ \\
\hline Inconvenient to use & $21(7.87)$ \\
\hline No need, follow natural family planning & $15(5.62)$ \\
\hline
\end{tabular}

(Multiple choices)

\section{DISCUSSION}

Current users of contraception in the present study was found to be $(64.41 \%)$ that is similar to national rate NFHS- $3^{9}(66.9 \%)$ and DLHS-3 ${ }^{12}(60.2 \%)$ while greater than studies conducted by Sharma $\mathrm{AK}^{2}(42.9 \%)$ and Kansal $\mathrm{A}^{6}(49.86 \%)$ and less than studies conducted by Takkar $\mathrm{N}^{8}(81.1 \%)$ and Chandhik $\mathrm{N}^{13}(73.5 \%)$.

Tubectomy $(80.33 \%)$ followed by Condom (10.97\%) were contraceptive method of choice among couples participated in present study. Similar findings reported in national survey NFHS $-3^{9}$ (Tubectomy $-44.2 \%$, followed by Condom $-9.8 \%$ ) and DLHS-3 ${ }^{12}$ (Tubectomy - $34.6 \%$ followed by $10.6 \%$ ). Also in study conducted by Kansal $\mathrm{A},{ }^{6}$ major proportion $(28.88 \%)$ was of tubectomy acceptors followed by condom users $(11.68 \%)$.

In present study, there was significant association between contraceptive practice and age, type of family, education, age at marriage, years of marriage and no. of children of study subject while no significant association with religion, socioeconomic status, working status, age at first child birth and no. of abortions by chi-square test. In a study conducted by Pushpa $\mathrm{SP}^{5}{ }^{5}$ significant relationship was observed between, contraceptive practice and age, type of family, working status, education and no. of children and no significant relationship with religion. Bisoi $\mathrm{S}^{14}$ found there was significant association between contraceptive use and age, type of family, education, socioeconomic status, age at first child birth and no. of children while no significant association with religion and age at marriage. Sharma $\mathrm{AK}^{2}$ reported significant relationship between contraceptive practices and education and No. of children.

In study conducted by Bhasni $\mathrm{SK},{ }^{15}$ Chandhik $\mathrm{N},{ }^{13}$ and Murarkar Sujata $\mathrm{K}^{3}$ most common reason behind not accepting contraceptive was desire to have children as family not completed followed by fear of side effect similar to present study. Mishra Vinod $\mathrm{K}^{16}$ found health method related problem and failure $(37.8 \%)$ followed by desire of children $(28.9 \%)$ as commonest reason behind not using contraceptive.

\section{CONCLUSION}

Contraceptive practices show pattern similar to national level data. Tubectomy was most preferred contraceptive method while only one couple preferred vasectomy. Various socio-demographic and reproductive variables had impact on contraceptive practices. Majority couples not using contraceptive desire to children to complete family.

\section{Funding: No funding sources}

Conflict of interest: None declared

Ethical approval: The study was approved by the institutional ethics committee

\section{REFERENCES}

1. Najafi-Sharjabad F, Zainiyah Syed Yahya S, Abdul Rahman H, Hanafiah Juni M, Abdul Manaf R. Barriers of modern contraceptive practices among Asian women: a mini literature review. Glob J Health Sci. 2013;5(5):181-92.

2. Sharma AK, Grover V, Agarwal OP, Dubey KK, Sharma S. Patterns of Contraceptive Use by Residents of a Village in South Delhi. Indian J Public Health. 1997;41(3):75-8.

3. Murarkar SK, Soundale SG, Lakade RN. Study of contraceptive practices and reasons for not accepting contraceptives in rural India: Chennai village as a case study. Indian J Sci Technol. 2011;4(8):915-6.

4. Sanku D, Sankar G. Fertility pattern and its correlates in North East India. J Hum Ecol. 2009;26(2):145-52.

5. Pushpa SP, Venkatesh R, Shivaswamy MS. Study of fertility pattern and contraceptive practices in a rural area - a cross-sectional study. Indian J Sci Technol. 2011;4(4):429-31.

6. Kansal A, Chandra R, Kandpal SD, Negi KS. Epidemiological correlates of contraceptive prevalence in rural population of Dehradun district. Indian J Community Med. 2005;30(2):60-2.

7. Singh RK. Narendra, Devi T. Ibetombi, Devi Th. Bidhumukhi, Singh Y. Manihar, Devi Th. Nonibala, Singh N. Sharat. Acceptability of contraceptive methods among urban eligible couples of Imphal, Manipur. Indian J Community Med. 2004;29(1):137.

8. Takkar N, Goel P, Saha PK, Dua D. Contraceptive practices and awareness of emergency contraception in educated working women. Indian $\mathrm{J}$ Med Sci. 2005;59(4):143-9.

9. IIPS. NFHS-III (2005-2006) factsheet Maharashtra, 2007. Available at: http://www.nfhsindia.org. Accessed 20 March 2014. 
10. Abramson JH, Abramson ZH. Sampling. In: Abramson JH, Abramson ZH, eds. Survey Methods in Community Medicine, Epidemiological Research, Program Evaluation, Clinical Trials. 5th ed. US: Elsevier Limited; 1999: 102.

11. Patrias K. Citing medicine: the NLM style guide for authors, editors, and publishers. In: Wendling DL, eds. Technical Edition. 2nd ed. Bethesda (MD): National Library of Medicine (US); 2007.

12. IIPS. District level household and facility survey 2007-08. In: IIPS, eds. Fact Sheets India. Mumbai: Ministry of Health and Family Welfare Government of India. International Institute for Population Sciences (Deemed University); 2009.

13. Chandhick N, Dhillon BS, Kambo I, Saxena NC. Contraceptive knowledge, practices and utilization of services in the rural areas of India (An ICMR task force study). Indian J Med Sci. 2003;57(7):303-10.

14. Bisoi S, Haldar A, Baur B, Mishra R, Dasgupta U, Banerjee L. Contraceptive practice: an experience from rural West Bengal, India. Int J Basic Appl Med Sci. 2012;2(1):174-8.

15. Bhasin SK, Pant M, Metha M, Kumar S. Prevalence of usage of different contraceptive methods in East Delhi - a cross sectional study. Indian J Community Med. 2005;30(2):53-5.

16. Mishra VK, Retherford RD, Nair PS, Feeney G. Reasons for discontinuing and not intending to use contraception in India. International Institute for Population Sciences, East-West Center, Population and Health Studies, Honolulu, Hawaii, U.S.A.;1999 National Family Health Survey Subject Report No. 13.

DOI: $10.5455 / 2320-1770 . i j r c o g 20150412$

Cite this article as: Sahu PC, Inamdar IF, Doibale MK. Contraceptive practices: an experience from ever married women in a city of Maharashtra, India. Int J Reprod Contracept Obstet Gynecol 2015;4:349-54. 